\title{
Socio-demographic and Clinical Characteristics of Regular Blood Donors Receiving Free Blood Bags at The National Blood Transfusion Center in Côte d'Ivoire
}

\author{
Sekongo Yassongui Mamadou ${ }^{1,}$, Konan Sidoine $^{2}$, Kouamenan Sidonie ${ }^{3}$, Tiembre Ibrahima ${ }^{4}$, \\ Tchimou Jeremie ${ }^{2}$, Konate Seidou ${ }^{5}$ \\ ${ }^{1}$ Department of Training and Research, National Blood Transfusion Center, Abidjan, Côte D'Ivoire \\ ${ }^{2}$ Distribution Service, National Blood Transfusion Center, Abidjan, Côte D'Ivoire \\ ${ }^{3}$ Hemovigilance Service, National Blood Transfusion Center, Abidjan, Côte D'Ivoire \\ ${ }^{4}$ Epidemiological Surveillance, National Institute of Public Hygiene (INHP), Abidjan, Côte D'Ivoire \\ ${ }^{5}$ National Blood Transfusion Center, Abidjan, Côte D’Ivoire \\ Email address: \\ sekyass@yahoo.fr (S. Y. Mamadou) \\ ${ }^{*}$ Corresponding author
}

To cite this article:

Sekongo Yassongui Mamadou, Konan Sidoine, Kouamenan Sidonie, Tiembre Ibrahima, Tchimou Jeremie, Konate Seidou. Sociodemographic and Clinical Characteristics of Regular Blood Donors Receiving Free Blood Bags at The National Blood Transfusion Center in Côte d'Ivoire. American Journal of Biomedical and Life Sciences. Vol. 8, No. 1, 2020, pp. 11-14. doi: 10.11648/j.ajbls.20200801.13

Received: January 12, 2020; Accepted: January 21, 2020; Published: February 4, 2020

\begin{abstract}
The objective of this study is to review the activities of free delivery of blood bags to the regular blood donors at the National Blood Transfusion Center of Abidjan Treichville. Il was a descriptive cross-sectional study that took place at the National Blood Transfusion Center in Abidjan from 1 January to 31 March 2015. Were Included in the study all regular blood donors who presented themselves for free blood bags at the blood distribution service in Treichville during the defined period. 74 regular blood donors were included. The data has been saved and processed by Epi info 6.04Fr. The age group of $32-41$ years predominated with $40.55 \%$ followed by that of $22-31$ years with $27.03 \%$. For the beneficiaries, to equal value, the free of blood bags for mother and child predominated with $22.97 \%$ followed by the husband with $21.62 \%$ of cases of free In $55.40 \%$ of cases, the justification for the transfusion was severe anemia. At the end of our study, we can retain for our study population, that they are young blood donors having generally benefited from a single case of free. Regarding the right-holders for free to regular blood donors, we noted a predominance with equal values for the mother and for the child. It would be interesting for the whole population to feel concerned about the donation of blood because each of us is a potential transfused patient.
\end{abstract}

Keywords: Free, Blood Bag, National Blood Transfusion Center, Abidjan

\section{Introduction}

The National Blood Transfusion Center (CNTS) is the only operator authorized in Côte d'Ivoire to collect, process and distribute blood.

This business requires regular and motivated blood donors. With this in mind, the CNTS has set up a policy of free access (blood bags, biological analyzes) for regular blood donors. The beneficiaries of free blood donations from regular blood donors are the father, mother, husband and children under the age of eighteen. Our study focuses on free blood products.

Some African countries like Burkina Faso have adopted a replacement donation policy. the blood bags are sold in place of a family donor [1].

In Côte d'Ivoire, like many countries, the price of blood products is fixed by law, and covers the various operations necessary before their use: sampling, preparation, analyzes, storage and distribution [2]. Blood donation is volunteer, voluntary and free. The blood donor therefore comes 
altruistically without any real compensation.

Relational Marketing carried out by certain blood transfusion centers has made it possible, such as the French Blood Establishment (EFS), to increase the number of blood donors and above all to retain them [3, 4]. In Côte d'Ivoire, incentives to donate blood have been taken by the authorities, including free blood products for all blood donors and their ascendants and descendants [5]. In the absence of data to assess the effectiveness of free blood products for blood donors on their motivation to donate, we conducted this study whose objective is to describe the socio-demographic and clinical characteristics of blood donors benefiting from the free blood bags, at the CNTS in Abidjan Treichville.

\section{Methodology}

This was a descriptive cross-sectional retrospective study which took place at the CNTS in Abidjan, Côte d'Ivoire, from January 1 to March 31, 2015, i.e. three months. It involved 74 blood donors who benefited from free blood products (red blood cell, platelet or plasma concentrates) during the study period. We included in the study all the blood donors who presented themselves for free of blood bags at the service of distribution of blood products. The data were collected using a quiz containing the epidemiological and clinical parameters of blood donors requesting blood products. This survey sheet was completed using a register dedicated only to frees granted to blood donors.

Data processing and analysis was performed on Excel 2010 .

\section{Result}

\subsection{Socio-demographic Profile}

Table 1. Distribution of blood donors by age and place of residence.

\begin{tabular}{llll}
\hline Parameters & & Numbers $\mathbf{( N = 7 4 )}$ & Percentage \\
\hline & Age Group & & \\
& $22-31$ & 20 & 23,03 \\
& $32-41$ & 30 & 40,55 \\
& $42-51$ & 13 & 17,57 \\
& $52-61$ & 5 & 6,75 \\
min: 22 ans & $62-71$ & 6 & 8,1 \\
& maximum: 65 ans & moyenne: 33 ans & \\
& Residence & & \\
& Treichville & 6 & 8,1 \\
& Yopougon & 23 & 31,1 \\
& Marcory & 0 & 0 \\
& Adjame & 2 & 2,7 \\
& Koumassi & 2 & 2,7 \\
& Williamsville & 4 & 5,4 \\
& Plateau & 0 & 0 \\
& Port Bouet & 7 & 9,45 \\
& Cocody & 6 & 8,1 \\
& Abobo & 17 & 23 \\
& Abidjan Suburbs & 7 & 9,45 \\
\hline
\end{tabular}

The age group of 32-41 years predominated with $40.55 \%$ followed by that of 22-31 years with $27.03 \%$.
The town of yopougon predominated with $31.1 \%$ followed by the municipality of Abobo with $23 \%$.

\subsection{Characteristics of Freebies Pockets of Blood}

Table 2. Distribution of blood donors according to the number of free blood pockets.

\begin{tabular}{lll}
\hline Number of free pockets & Number $\mathbf{n}=\mathbf{7 4}$ & Percentage \\
\hline 1 & 62 & 83,8 \\
2 & 05 & 6,7 \\
3 & 04 & 5,4 \\
4 & 03 & 4,1 \\
\hline
\end{tabular}

In $83.8 \%$ of cases, regular blood donors were entitled to a free.

Table 3. Distribution of blood donors by entitlement.

\begin{tabular}{lll}
\hline having the right & Number $\mathbf{N}=\mathbf{7 4}$ & Percentage \\
\hline Mother & 17 & 22,97 \\
Father & 11 & 14,86 \\
Regular donor & 13 & 17,56 \\
Spouse & 16 & 21,62 \\
Children & 17 & 22,97 \\
\hline
\end{tabular}

At equal value, the mother and the child predominated with $22.97 \%$ followed by the husband with $21.62 \%$ of the cases of gratuity.

\subsection{Clinical Data}

Table 4. Distribution of freeze based on transfusion indications.

\begin{tabular}{lll}
\hline Diseases & Number $\mathbf{N}=\mathbf{7 4}$ & Percentage \\
\hline Hematuria & 2 & 2,70 \\
Heart failure & 1 & 1,35 \\
Osteosynthesis & 1 & 1,35 \\
Cervical cancer & 5 & 6,76 \\
Decompensated anémia & 41 & 55,40 \\
Malaria & 1 & 1,35 \\
Surgical intervention & 2 & 2,70 \\
Tumor & 3 & 4,05 \\
Pancreatitis & 1 & 1,35 \\
Thalassemia & 2 & 2,70 \\
Sikle cell desease & 1 & 1,35 \\
Diabetic gangrene & 2 & 2,70 \\
Vaginal Bleeding & 1 & 1,35 \\
Gastrointenstinal bleeding & 1 & 1,35 \\
Femur fracture & 1 & 1,35 \\
Acute leukemia & 1 & 1,35 \\
Dialysis & 5 & 6,76 \\
Trauma & 1 & 1,35 \\
Appendix plastron & 1 & 1,35 \\
Myomectomy & 1 & 1,35 \\
\hline
\end{tabular}

In $55,40 \%$ of the cases the justification of the transfusion was the severe anemia.

\section{Discussion}

The average age of our study population was 33 years with extremes of 22 years and 65 years. It was a young population. Our data differ from those reported in the various activity reports of the CNTS of Côte d'Ivoire. Indeed, these different reports noted an average age of 25 years with a 
predominance of the 18 to 30 years age group in $51 \%$ of the cases $[5,6]$. This difference between the data of our study and that of the various activity reports of the CNTS of Côte d'Ivoire can be explained by a selection bias related to the subject of our study which only concerns donors benefiting from pockets of free blood for a parent. In Africa, most studies report very young populations of blood donors with an average age of 26 years [7-10]. Diarra A. in Mali observed an average age of 21 years (range: 1 and 62 years); children represented $32 \%$ and adults $68 \%$ [10].

The work of the French-speaking research group in blood transfusion has reported a population of usually young blood donors, with an average age of 26 years (17-60 years) [11].

In $31.8 \%$ of the cases, our blood donors lived in the town of Yopougon and then in $23 \%$ of the cases in the town of Abobo. This could be explained by the fact that the commune of Yopougon is the largest in area of Abidjan where there is a university hospital with the only clinical hematology service in Côte d'Ivoire.

Regarding the number of free blood bags received, in $83.8 \%$ of cases, regular blood donors have only one free blood bag. Each donor received an average of 1 free blood bag regardless of the number of bags requested. This is due to the fact that; blood is not enough to meet all national demands. Indeed, Côte d'Ivoire can only meet $60 \%$ of national blood needs. Consequently, the CNTS is obliged to rationalize the blood and to donate only one pocket per patient.

As regards the beneficiaries of regular blood donors, with equal values, the mother and the child predominated in $22.97 \%$ of the cases, followed by the spouse in $21.62 \%$ of the cases and finally in $17,56 \%$ of cases, the regular blood donor, was the beneficiary. The predominance of transfusion in mothers and children could be explained by the fact that this population group is the most prone to transfusion; in mothers due to childbirth [12] and gynecological conditions such as fibroids [12], and in children due to conditions such as severe anemic type malaria [13-16]. Also the blood donor is the beneficiary to say that each human being is a potential transfused; hence the importance of donating blood in a selfless [17]

It is therefore important that blood transfusion centers can develop donation marketing $[18,19]$ strategies in order to retain blood donors wherever this is done in France [20].

In $55.40 \%$ of the cases, the justification for the transfusion was severe anemia followed by equal values of the cases of dialysis and cervical cancer in $6.76 \%$ of the cases. This could be explained by the fact that dialysis requires blood and for cervical cancer, transfusion is justified by chemotherapy. these are the classic indications for blood transfusion as reported in the literature [21-23].

\section{Conclusion}

At the end of our study, it is clear that blood transfusion is a saving act which also benefits the blood donor. However, the insufficiency of blood products makes it difficult to meet the needs, for free blood bags, from donors.
In order to increase the number of blood donors, it would be desirable for the National Blood Transfusion Center of Côte d'Ivoire, to develop a real policy of Social Marketing of donation, like what is done in Europe and in certain developed countries.

\section{Conflict of Interest}

The authors declare that there is no conflict of interest for this manuscript.

\section{References}

[1] Campagne d'information sur le CNTS au Burkina Faso par la directrice. www.tout sur la transfusion.com internationale. 17 Oct. 2015.

[2] F. A. Q- Donneur de sang.be-Service du sang. WWW.transfusion.be/ fr/ faq/.

[3] HAL-SHS Attirer et fidéliser les donneurs de sang https://halshs.archives-ouvertes.fr > document.

[4] Sylvie Daigneault: Le marketing dans l'univers du don de sang. Tranf Clin Biol. 2007, 14 (1): 147-151.

[5] Rapport d'activité du centre national de transfusion sanguine (CNTS) de Côte D'Ivoire. Conseil de gestion (COGES) Février 2014. Archives CNTS RCI.

[6] Rapport d'activité du centre national de transfusion sanguine (CNTS) de Côte D'Ivoire. Conseil de gestion (COGES) du 11 Mars 2016. Archives CNTS RCI.

[7] Tagny CT, Diane Kouao M, Touré H, Gargouri J, Fazul A. S, Ouattara S, Anani L, Othmani H, Feteke L and All. Transfusion safety in francophone African countries: an analysis of strategies for the medical selection of blood donors. Transfusion 2012; 52 (1): 134-43.

[8] Tagny CT, Mbanya D, Tapko JB, Lefrere JJ. Blood safety in sub-Saharan Africa: a multi-factorial problem. Transfusion. 2008; 48 (6): 1256-61.

[9] Nébié KY, Olinger CM, Kafando E, Dahourou H, Diallo S, Kientega Y, Domo Y, Kienou K, Ouattara S, Sawadogo I, Ky L, Muller CP. Lack of knowledge among blood donors in Burkina Faso (West Africa); potential obstacle to transfusion security. Transfus Clin Biol. 2007; 14 (5): 446-52.

[10] Diarra A, Kouriba B, Baby M, Murphy E, Lefrere J-J. HIV, $\mathrm{HCV}, \mathrm{HBV}$ and syphilis rate of positive donations among blood donations in Mali: lower rates among volunteer blood donors. Transf. Clin. et biol. 2009, 16 (5-6): 444-447.

[11] Tagny C. T, Murphy EL, Lefrère JJ. et Groupe de recherches transfusionnelles en Afrique francophone. Le groupe de Recherche Transfusionnelles d'Afrique francophone: bilan des cinq premières années. Transfus. Clin. Biol. 2014; 21 (1): $37-$ 42.

[12] Ministère de la Santé et de la Lutte contre le sida (MSLS), Institut national de la statistique, Ministère d'État, et al.. Enquête démographique et de santé à indicateurs multiples 2011-2012 - Côte d'Ivoire. Disponible sur https://www.dhsprogram.com $>$ pubs $>$ pdf. 
[13] Institut National de la Statistique (INS), Ministère du Plan et du Developpement (MPD), Programme National de Lutte contre le Paludisme (PNLP), Ministère de la Santé et de l'Hygiène Publique (MSHP): Enquête de Prévalence Parasitaire du Paludisme et de l'Anémie (EPPA-CI), Décembre 2016. Disponible sur https://dhsprogram.com/pubs/pdf/FR330/FR330.pdf.

[14] S. Zlotkin, S. Newton, A. M. Aimone, et al. Effect of iron fortification on malaria incidence in infants and young children in Ghana: a randomized trial JAMA, 310 (2013), pp. 938-947.

[15] F. S. Asobayire, P. Adou, L. Davidsson, et al. Prevalence of iron deficiency with and without concurrent anemia in population groups with high prevalences of malaria and other infections: a study in Cote d'Ivoire Am J Clin Nutr, 74 (2001), pp. 776-782.

[16] A. A. Righetti, R. Wegmuller, D. Glinz, et al. Effects of inflammation and Plasmodium falciparum infection on soluble transferrin receptor and plasma ferritin concentration in different age groups: a prospective longitudinal study in Cote d'Ivoire Am J Clin Nutr, 97 (2013), pp. 1364-1374.

[17] Le Gall-Ely M. Gonzalez C. et Urbain C. (2009), Donner: C'est donner? Une étude ethnographique de la diversité des expériences de don, Journée de Recherche en Marketing de Bourgogne.

[18] WHO. Vers $100 \%$ des donc de sang volontaires. https://www.who.int/bloodsafety/publications/9789242599695 pdf?ua $=1$.

[19] Win de Kort. Manuel de Management des donneur. 2010 https://www.sanquin.org/binaries/content/assets/en/research/d onor-studies/fr-manual-de-management-des-donneurs---part1.pdf.

[20] Laure Ambroise, Isabelle Prim-Allaz, Martine Séville. Attirer et fidéliser les donneurs de sang. 2010. ffhalshs-00519515v2f.

[21] Haute Autorité de Santé (HAS). Transfusion de globules rouges homologues: produits, indications, alternatives. https://www.has-sante.fr/upload/docs/application/pdf/201502/transfusion_de_globules_rouges_homologues_produits_indications_alternatives_-_recommandations.pdf.

[22] Transfusion de produits sanguins labiles: indications, complications. Hémovigilance http://www.cnerea.fr/UserFiles/File/national/desc-des/livremasson-2015/cardio/transfusion.pdf.

[23] Oliver Karam et Marisa Tucci. Massive Transfusion in Children, Transfusion Medicine Reviews, 2016, 30; 4: 213-216. 